\title{
Pathophysiology of Demineralization, Part I: Attrition, Erosion, Abfraction, and Noncarious Cervical Lesions
}

\author{
W. Eugene Roberts ${ }^{1}$ (i) $\cdot$ Jonathan E. Mangum ${ }^{2} \cdot$ Paul M. Schneider $^{3}$
}

Accepted: 15 December 2021 / Published online: 7 February 2022

(C) The Author(s) 2022

\begin{abstract}
Purpose of the Review Compare pathophysiology for infectious and noninfectious demineralization disease relative to mineral maintenance, physiologic fluoride levels, and mechanical degradation.

Recent Findings Environmental acidity, biomechanics, and intercrystalline percolation of endemic fluoride regulate resistance to demineralization relative to osteopenia, noncarious cervical lesions, and dental caries.

Summary Demineralization is the most prevalent chronic disease in the world: osteoporosis (OP) $>10 \%$, dental caries $\sim 100 \%$. OP is severely debilitating while caries is potentially fatal. Mineralized tissues have a common physiology: cell-mediated apposition, protein matrix, fluid logistics (blood, saliva), intercrystalline ion percolation, cyclic demineralization/remineralization, and acid-based degradation (microbes, clastic cells). Etiology of demineralization involves fluid percolation, metabolism, homeostasis, biomechanics, mechanical wear (attrition or abrasion), and biofilm-related infections. Bone mineral density measurement assesses skeletal mass. Attrition, abrasion, erosion, and abfraction are diagnosed visually, but invisible subsurface caries $<400 \mu \mathrm{m}$ cannot be detected. Controlling demineralization at all levels is an important horizon for cost-effective wellness worldwide.
\end{abstract}

Keywords Fluoride $\cdot$ Biomechanics $\cdot$ Percolation $\cdot$ Remineralization $\cdot$ Hydroxyapatitie $\cdot$ Enamel

\section{Introduction}

Demineralization of mineralized tissues has a common pathophysiology which may be infectious or noninfectious (Fig. 1). Part I of this review introduces integrated concepts for

This article is part of the Topical Collection on Craniofacial Skeleton

\author{
W. Eugene Roberts \\ werobert@iu.edu \\ Jonathan E. Mangum \\ jon.mangum@unimelb.edu.au \\ Paul M. Schneider \\ pmschn@unimelb.edu.au
}

1 Indiana University \& Purdue University at Indianapolis, 8260 Skipjack Drive, Indianapolis, IN 46236, USA

2 Department of Biochemistry and Pharmacology, Dentistry and Health Sciences, University of Melbourne, Corner Grattan Street and Royal Parade, Parkville, Victoria 3010, Australia

3 Melbourne Dental School, University of Melbourne, 720 Swanston St, Melbourne, Victoria 3010, Australia noninfectious demineralization with an emphasis on common clinical disorders. Part II discusses the superimposed variable of infection. Teeth and jaws have long been appreciated as the most heavily loaded mineralized tissues in the body [1]. The mandible is a cantilever exposed to high levels of bending and torsion $[2,3]$, so the remodeling (turnover) rate to repair microdamage is $\sim 44 \% /$ year which is three times higher than for the femur $[4 \cdot \bullet]$. Demineralization is a disorder of structure and function [5] that is common to all mineralized tissues. The etiology involves intercrystalline fluid flow [6], metabolism [7], homeostasis [8], biomechanics [9], mechanical wear (attrition or abrasion) [10,11], and/or biofilm-related infections [12]. Hydroxyapatite (HA) of nonliving enamel as well as the living mineralized tissues (dentin, cementum, bone) is maintained by ion exchange via percolation. Dental modeling and remodeling can occur to a limited degree, but only bone is continuously turned over with apposition and resorption [13-17]. The mineral component of all mineralized tissues evolves over time by ion exchange via fluids percolating through the microporosity of hard tissue $[6,18,19]$. An internal decrease in the mass of mineralized tissue may be reversible, but external degradation of teeth is irreversible [19]. 
Osteopenia and osteoporosis (OP) have a prevalence of $\sim 55 \%$ and $>10 \%$ respectively so low skeletal mass is the most common form of bone demineralization [20, 21]. Dental demineralization disorders have a much higher prevalence: $85-100 \%$ worldwide, and almost everyone $(100 \%)$ is affected over a lifetime (Fig. 1) [22-27]. Loss of mineralized tissue has profound clinical manifestations such as relatively atraumatic fractures and pain [21, 28], as well as compromises in dentofacial esthetics, function, and well-being [22-26].

Dentistry and medicine are closely related disciplines; regular dental care is directly related to overall health and wellness [29]. Demineralization disorders affect all mineralized tissues. The pathogenesis is variable but typically involves some form of acidic demineralization: environment, clastic cells or microbes [12, 14-16]. Biomechanics is essential physiology for mineralized tissue, but excessive or inadequate loading may be pathologic. OP is a metabolic problem often associated with insufficient weight-bearing exercise [30]. Occlusal wear facets are manifestations of mechanical attrition associated with a gritty and/or acidic diet as well as parafunctional habits (chronic clenching or bruxism) [31]. Bruxism (grinding) results in severe attrition of teeth, but chronic clenching (static loading) is associated with tooth fractures as well as temporomandibular joint (TMJ) degeneration [32]. Dental erosion, abrasion, and abfraction often have a dual etiology involving acidic demineralization and mechanical flexure [25-27].

Caries is a chronic bacterial infection due primarily to Streptococcus mutans [33-36]. It is communicable; the sterile mouth of a newborn child is inoculated with the virulent cariogenic bacteria. Dental caries is by far the most prevalent human disease in the world resulting in an annual loss of worldwide productivity of more than USD \$27 billion [23], and the overall burden is increasingly among adults $[22,24]$. In addition, caries is a major detriment to military readiness [34] that may be most efficiently managed with remineralization procedures prior and during deployment [35]. Because it is primarily an infectious demineralization disorder, the pathogenesis of caries is discussed in detail in part II of this review. However, the interactive pathophysiology of carious and noncarious lesions is relevant for part I.

Mineralized tissues are relatively rigid elements capable of resisting environmental challenges. Health and disease in the oral cavity are related to the specific development and morphology of craniofacial hard structures. Oral demineralization may result in substantial health problems. Emphasis on prevention and early treatment is the most expedient approach [36]. Enlightened management of dental disease requires a careful consideration of the similarities and differences between the dentition and the skeleton [37]. A tooth is a hybrid structure, septic crown with a sterile root, that is designed for heavy function. Enamel is a nonvital mineralized tissue with optimal properties to withstand the challenging oral environment [38]. In contrast, bones, dentin, and cementum are vital biologic tissues formed by osteoblasts, odontoblasts, and cementoblasts, respectively. These anabolic cells extend living processes into adjacent mineralized tissues composed of collagen matrices [18, 19, 39]. Noncollagenous proteins such as osteopontin [40] and extracellular matrix proteins [41] regulate mineralization. $\mathrm{HA}$ is a crystalline form of calcium $\left(\mathrm{CA}^{++}\right)$, hydroxyl $\left(\mathrm{OH}^{-}\right)$, and phosphate ions $\left(\mathrm{PO}_{4}^{-3}\right)$. It is the biologic mineral configuration for bones, teeth, and skin, but it is rarely encountered in geologic structures (natural rocks) [42]. Organic matrices for teeth and bones are specifically cross-liked and configured to accommodate the nucleation and crystal growth of HA crystals. Examination of the metabolism and pathophysiology of mineralized structures reveals similarities relative to acid resistance, mechanical loading, and susceptibility to infection $[19,25,26,43,44]$.
Fig. 1 The upper aspect of the flow chart defines the etiology of demineralization as a combination of acid, biomechanics, and percolation of intercrystalline fluid.

Demineralization is defined as a unique disease process. There are differential effects on the sterile bone and septic dentition compartments. Loss of mineralized tissue (osteopenia, noncarious cervical lesions, and caries) is collectively the most pandemic disease in the world (prevalence $\sim 100 \%$ ). See text for details

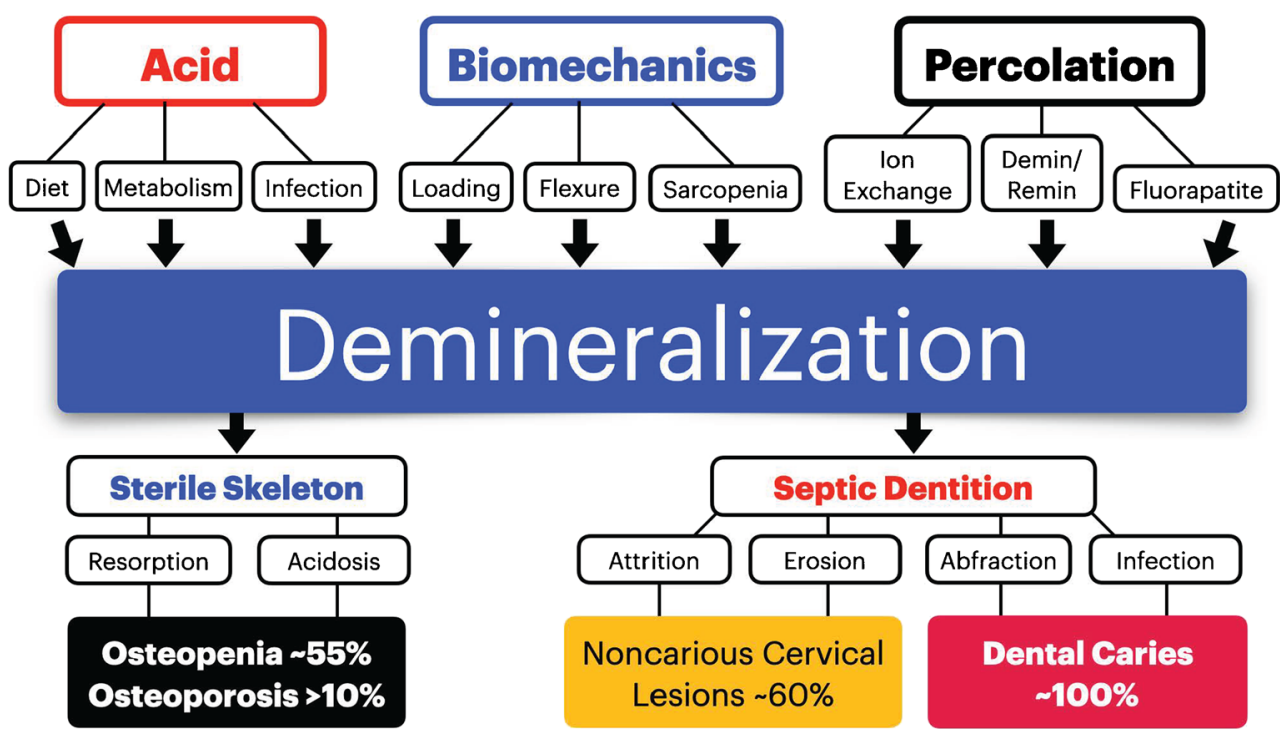




\section{Developmental Morphology}

Collectively, the stomatognathic system supports three principal life support functions: breathing, mastication, and mating success $[45,46]$. The maxilla and mandible are secondary bones that evolve following the embryonic patterning of the skeleton. After development of the gut, neural crest cells differentiate and migrate to the ventral surface of the embryo. They induce pharyngeal and facial mesoderm to form the specialized musculoskeletal structures of the head, pharynx, and neck [46]. Teeth develop within the jaws, erupt into the oral cavity, but remain anchored in bone. The vital root of a tooth is connected to the supporting alveolar process by a periodontal ligament (PDL), a stress-bearing, connective tissue interface that has bone modeling capability similar to periosteum [14, 37, 47]. Biomechanics, T-lymphocytes, and RANK-L control the site-specific osteoclastic resorption in the PDL similar to other osseous tissues [37, 47, 48]. Modeling is defined as a change in size or form of a bone [14] and remodeling is turnover: resorption of an internal cavity that is refilled with new bone $[16,17]$. Both cellmediated processes help adapt the functioning dentition to its supporting bone. Bone size and morphology are controlled by biomechanics: physiologic loads delivered by muscles, soft tissue posture, or applied mechanics [14, $37,47]$. Teeth can demonstrate anabolic modeling in the pulp chamber by forming reactionary or reparative dentin in response to varying forms of inflammatory stimuli, most notably dental caries $[49,50]$. In addition, there are two types of catabolic modeling that involve clastic cells: cervical [27] and mechanically-mediated root resorption (Fig. 2) [51]. Both of these resorption disorders are similar to the catabolic bone modeling of osteoclasts [14]. The only cell-mediated structural turnover for teeth is secondary cementum formation to refill a root resorption cavity $[37,52]$. Similar to bone, the dentition develops under sterile conditions within the maxilla and mandible. Teeth erupt through osseous tissue and mucosa resulting in the crown emerging into the septic environment of the oral cavity. In addition to dental-related support for mastication and respiration, the oral cavity participates in a complex physiology that affects systemic health at multiple levels [52].

All mineralized tissues are patterned by a unilateral genetic process, so, one side of the body is the mirror image of the other [39]. Long bones are patterned as primary events during passive embryonic development, i.e., prior to muscle development. However, the maxilla and mandible evolve as secondary structures in a dynamic environment after the muscles of mastication are formed and functioning $[45,46]$. The teeth are subsequently patterned within the jaws by the dental lamina. There is little environmental influence on tooth size and shape, e.g., antimeres are nearly identical bilaterally. On the other hand, bone form, size, and density are strongly affected by biomechanics [53]. For instance, sidedness of the limbs can vary considerably according to differential loading [54]. In effect, teeth are genetic constants, but mature bones are environmental variables.

\section{Dental Components}

The articulating crowns of teeth require a strong, dense, and stable material that is resistant to acidic attack and heavy loading. As the hardest substance in the body, enamel is a genetically distinct mineralized tissue that achieves its high density by a catabolic macromolecular mechanism [55] rather than mineralization of a collagen matrix [14, 37]. Forming dense enamel involves a unique genetic process. HA-like crystals (nanoribbons) form a matrix-like structure for initial mineralization that resorbs during maturation to enhance the density of an HA rod (prism) within its less mineralized sheath [55-57]. However, the initiation of enamel mineralization is like osteogenesis. Nucleation of the initial HA crystals form an individual prism via mineralized collagen fibers from the dentin that extend into the developing enamel [56]. Enamel formation involves unique matrix proteins: amelogenin, ameloblastin, and enamelin. In addition, proteases MMP-20 and KLK4 function during the secretory and maturation phases, respectively [57]. Amelogenins act as nanospheres (spacers) for the growth of enamel crystals (rods). To achieve maximum tissue hardness and density, the organic matrix for the developing enamel is digested and removed during the maturation process as the rods are mineralized [55-59]. Thus, enamel evolves as a living tissue that becomes nonvital with maturity.

It is a noncellular, avascular tissue that protects underlying vital tissues (dentin and pulp). Enamel is a rigid tissue that is susceptible to traumatic fracture, crack propagation, and acidic demineralization. Contamination with ions like carbonate can render it more soluble [35,36]. If the enamel is breached or malformed, the long-term prognosis for the affected tooth is questionable [60]. Enamel surfaces are composed of dense HA rods arranged in a configuration that is a similar for all primates [61]. The hybrid nonvital and vital morphology of teeth permits function as masticatory "battering rams" that transfer heavy loads to sterile supporting bone $[4,37,62]$. Dentin is a vital tissue sandwiched between a vascularized dental pulp and nonvital enamel (Fig. 2). The dentino-enamel junction (DEJ) is the vital frontier at the terminal ends of the dentinal tubules which are extensions of the odontoblasts that line the pulp. The DEJ is a critical patterning structure that is formed early in tooth development $[63,64]$. Dentin forms first and then it induces enamel at the DEJ interface. Once 
Fig. 2 Labial (left) and crosssectional (right) planes of a maxillary premolar show dental structures: enamel (E), dentin (D), pulp, cementum $(\mathrm{C})$, dentinoenamel junction (DEJ), and cementoenamel junction (CEJ). A noncarious cervical lesion (NCCL) is depicted in both planes. The multifactorial etiology for a NCCL is (1) toothbrush abrasion, (2) dietary acid, and (3) functional flexure. The line of force for non-axial and lateral loads (dotted lines) produce surface flexure in tension and compression that results in mechanical damage at the stress riser (star) along an enamel surface or within the maximum depth of a NCCL. See text for details

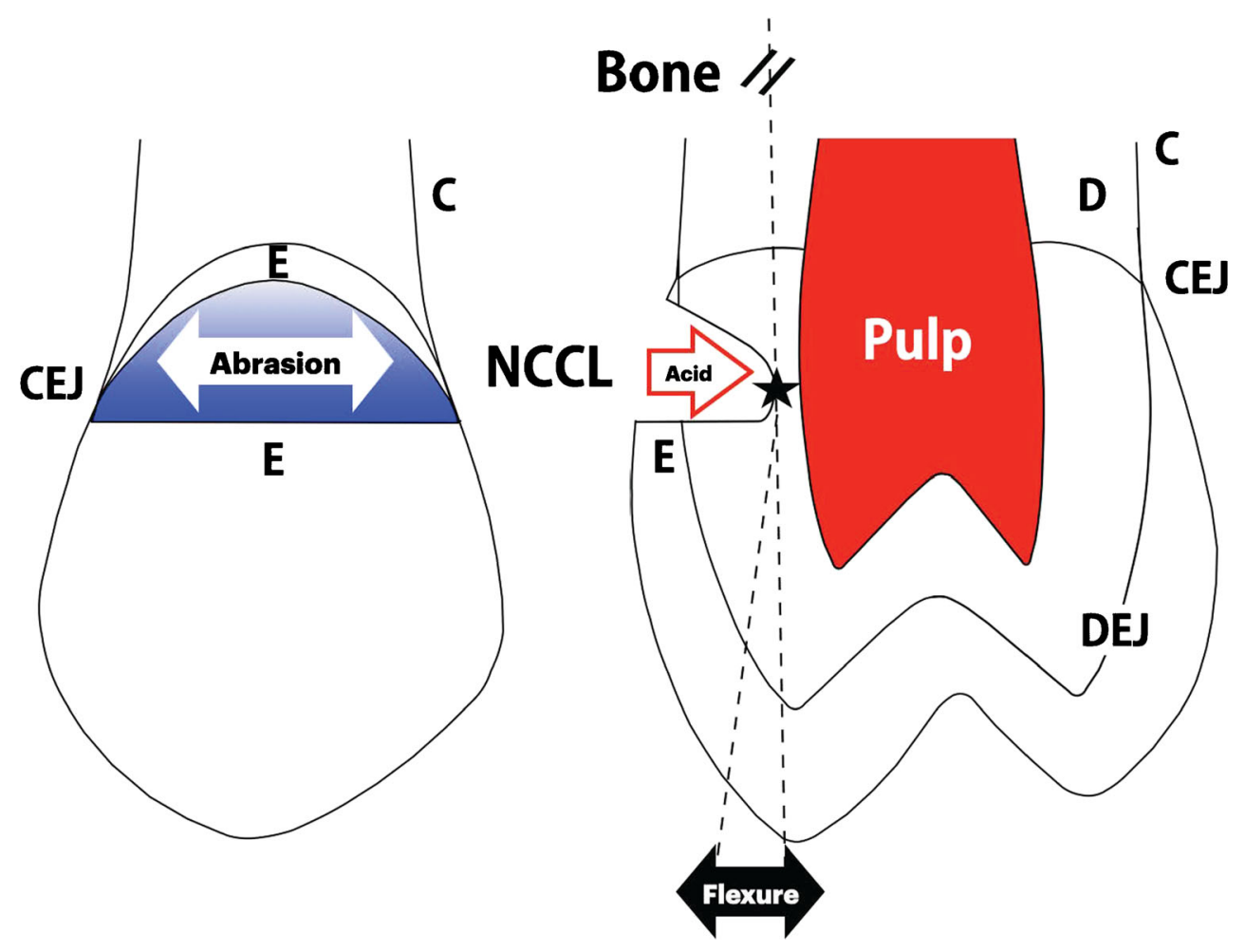

the enamel of the crown is patterned, dentin continues to grow in an apical direction to form the root. The mechanism involves $\beta$-catenin induction of Hertwig's epithelial sheath to form root dentin which is subsequently covered with vital cementum [65]. The interface of enamel and root cementum at the cervical margin of the crown is the cementoenamel junction (CEJ). Enamel is well designed to resist heavy loads, thermal gradients, chemical attacks, and sustained masticatory function [56]. Heavy impact loads are subsequently transferred to supporting bone [62, 66]. Under physiologic conditions, fatigue failure (spontaneous fracture) of teeth is controlled by: (1) PDL sensitivity to limit loading, and (2) physiochemical mineral turnover (demineralization, remineralization) to maintain material integrity $[19,48,66]$.

Teeth form in protected tooth buds within the jaw bones. After emerging into the oral cavity, a tooth has a limited capacity for growth as evidenced by completion of root and apex formation. Crown trauma and malformation are not physiologically repairable because enamel is a nonvital tissue. On the other hand, dentin and cementum are vital tissues, so a fractured root that is reduced and well-stabilized in an alveolus can heal much like a fractured bone via resorption of traumatized tissue, and formation of new cementum as well as dentin $[49,50,67]$. Furthermore, the pulp of traumatized tooth can revascularize to restore tooth vitality [68]. The closest parallel in bone physiology is when dead cortical bone (a sequestrum) remodels with vascularized cutting/filling cones to form vital secondary osteons $[13,16,17]$.

\section{Comparative Physiology}

In contrast to the limited growth and healing capacity of teeth $[49,50]$, bone is a highly adaptive mineralized tissue that grows, resorbs, remodels, adapts, and heals in a dynamic environment over a lifetime [13-17]. Osseous modeling, remodeling, and bone mass are controlled by hypothalamic, genetic, mechanical, endocrine, and inflammatory signals [37, 69-71]. Lamellar bone achieves toughness to resist fracture via a cross-lined collagen matrix that is progressively mineralized [37]. Osteoblasts produce new bone matrix that must mature for $7-10$ days prior to primary mineralization which is the active deposition of about $70 \%$ of the total bone mineral. The partially mineralized new osseous tissue undergoes a physiochemical secondary mineralization for the following 6-12 months to complete the bone formation process [14, $37,66]$. Secondary mineralization increases the hardness and stiffness of bone tissue [72] via a crystal growth process that is like the internal remineralization of enamel [19, 33, 35].

Metabolic activity of the dentition pales in comparison to the skeleton. Teeth play no direct role in $\mathrm{Ca}^{++}$hemostasis, but all mineralized tissues probably participate at least indirectly. Osteocytes and their canalicular processes transport $\mathrm{Ca}^{++}$between the bone fluid compartment and bone lining cells. Vitamin D-dependent cell membrane transport pumps $\mathrm{Ca}^{++}$ out of bone lining cells into the extracellular fluid (ECF) [37, 66, 73], which supports serum $\mathrm{Ca}^{++}$levels [73, 74]. Cyclic demineralization and remineralization in concert with remodeling (turnover) repair microdamage and support calcium 
homeostasis (Fig. 1) [73-77]. In addition, osteocytic osteolysis [75] supports serum Ca++ levels in both health and disease by promoting resorption around lacunae and canaliculi. Teeth are susceptible to age-related fatigue failure that may require clinical extraction or restoration [78]. On the other hand, bone has the potential to avoid spontaneous fracture by repairing microdamage accumulation with ongoing remodeling (turnover) [13, 16, 17, 37, 76]. Bone remodeling not only repairs microdamage but also helps to support serum $\mathrm{Ca}^{++}$levels [14, 73-75]. It bears repeating that the body of the mandible has the highest cortical bone remodeling rate in the body $[4 \cdot \bullet]$ because of extensive linear and torsional flexure $[2,3]$. In addition, the mineral fraction of bone is continuously modified with cell-mediated homeostasis as well as physiochemical ion exchange [73, 74]. Ultimately, osteopenia is a metabolic bone disorder reflecting long-term negative calcium balance. However, to a certain extent low bone mass is physiologically reversible $[70,71,73,74]$. Decreased muscle mass and grip strength (sarcopenia) are reliable indicators for revealing prevalence of osteopenia $(47.8 \%)$ and osteoporosis $(20.7 \%)$ in women aged 60-79years (Fig. 1) [79]. Internal demineralization of enamel is best managed by prevention and remineralization strategies [35, 80-82]. However, loss hard tissue on the surface of teeth by attrition or erosion is irreversible [83-85]. Extensive wear of the dentition is an indication for surgical and restorative procedures $[62,78]$.

\section{Percolation of Mineralized Tissue}

Enamel rods are organized as linear prisms oriented perpendicular to the DEJ. In a cross-sectional view, rods are shaped like keyholes [85] and separated by the peripheral inter-rod substance that originally guided the mineralization of each prism [38]. Since enamel functions under challenging septic conditions, it must be resistant to mechanical, chemical, and microbial attack [83-87]. As a nonvital tissue, the stability of enamel depends on its dense HA structure, low solubility potential, and continuous mineral maintenance by demineralization and remineralization [19, 80-82]. Microporosity within dense enamel is permeable to water and ions but not to larger structures such as microbes, biofilm, and food. In addition, enamel is resistant to demineralization because of a high solubility product that renders it less susceptible to acidic attack [87-89].

Clinically, sound enamel appears to be a solid prism, but the HA crystals are actually separated by small intercrystalline spaces that are more prominent in the rod sheaths [81, 89-93]. Hypomineralization creates a slightly porous structure that contains increased water and organic material [89-91]. This pattern of differential mineralization is associated with changes in modulation of the enamel-forming cells (ameloblasts) during the maturation stage $[59,92]$. The rod sheath mineral (inter-rod substance) is not as tightly packed so it can serve as a path for acidic demineralization [93]. This problem is best controlled by percolation of optimal levels of fluoride ions $\left(\mathrm{F}^{-}\right)$to form a gradient of fluorapatite (FA) that is most concentrated at the enamel surface. Fluoride-rich apatite is deemed FA. Micropores connecting the intercrystalline spaces allow enamel to function as a semi-permeable material [55, $80,81]$ that restricts bacteria and large molecules, but allow the passage of water and ions, particularly $\mathrm{Ca}^{++}, \mathrm{PO}_{4}{ }^{3-}, \mathrm{OH}^{-}$, and $\mathrm{F}^{-}$. Enamel like all other mineralized tissues is exposed to continuous cycles of mineralization and demineralization [19, $33,89]$. The continuous percolation of ionic fluid through the mineral fraction provides deep remineralization of HA which may involve substitution of $\mathrm{F}^{-}$for $\mathrm{OH}^{-}$to produce $\mathrm{FA}^{-}$[89]. This mechanism is more efficient for inter-rod substance (enamel sheath) because it has greater intercrystalline porosity [93]. Mineralized tissue fluids contain $\mathrm{Ca}^{++}, \mathrm{PO}_{4}{ }^{3-}$, and $\mathrm{OH}^{-}$ ions that are released from or deposited into the HA fraction. Like bone [6,94], there is a constant percolation of fluids and ions through enamel and dentin into the vascularized pulp. The flow of water and ions, particularly optimal levels of $\mathrm{F}^{-}$, through the dental mineralized tissues plays an important role for maintaining and adapting the mineral fraction (Fig. 1) [56, 80-82]. There are no reports that fluid flow through dental tissues supports systemic metabolism, but all mineralized tissues probably contribute to mineral homeostasis directly or indirectly.

There is a posterior flow of saliva from the minor, sublingual, and parotid salivary glands through the mouth and down the pharynx into the esophagus [95]. Saliva contains buffers such as bicarbonate to help control acidity in the diet and that produced by oral bacteria [96]. Similar to the extracellular and bone fluids of osseous tissue, water, and ions from the saliva flow into and through exposed oral hard tissues. Enamel is typically the oral interface for mineralized tissue with saliva, but cementum and even dentin may be exposed in the oral cavity if there is soft tissue recession and abrasion. As teeth erupt, saliva forms a thin coating of acquired pellicle on enamel surfaces. Pellicle is a protein layer rendering enamel less susceptible to demineralization [96-98]; however, it also serves as the base for plaque which may contribute to both caries and acidic erosion in a septic environment [98]. The closest parallel in bone physiology for dental pellicle is the thin layer of unmineralized osteoid which protects new bone from surface resorption. ${ }^{37}$

\section{Fluorine}

Fluorine in its ionic form $\mathrm{F}^{-}$is an important physiologic variable for mineralized tissue structure and function [94, 99, 100]. Sodium fluoride (NaF) via the diet, oral administration, and/or drinking water [99] is very effective for preventing 
demineralization particularly when optimal levels of the ion are present in ECF at the time the outer layers of enamel are formed (say age 2-10years) [101-103]. Despite broad-based opposition to fluoridation for many years, there are no scientific risks with $\mathrm{F}^{-}$use as promoted in dentistry [104, 105]. However, the accumulative dose of $\mathrm{F}^{-}$including absorption spikes in ECF should not exceed 1part per million (ppm) to avoid fluorosis [106]. With respect to noncavitated white spot lesions (WSLs), $\mathrm{F}^{-}$is a double-edged sword. $\mathrm{F}^{-}, \mathrm{Ca}^{++}$, and $\mathrm{PO}_{4}{ }^{3-}$ are relatively small ions that readily penetrate the intercrystalline spaces of enamel to achieve remineralization [80-82, 101-103]. A high dose of topical $\mathrm{F}^{-}$may be counterproductive because it contributes to a dense (hypermineralized) surface veneer of FA that inhibits the flow of the $\mathrm{Ca}^{++}$and $\mathrm{PO}_{4}{ }^{3-}$ through enamel [80-82]. The physiologic demineralization and remineralization cycle is an effective mechanism for introducing optimal doses of $\mathrm{F}^{-}$ deep into the mineral component of all mineralized tissues $[80,89,94]$. Bone achieves demineralization of fully mineralized tissue with osteocytic osteolysis [75] or subsurface channeling via osteoclasts [15]. Enamel mineral can turnover via percolation through intercrystalline micropores $[97,98]$ or subsurface demineralization and remineralization $[19,33]$. Internal demineralization contributes to porosity of bone [20, 21] and enamel [80-82, 101-103]. Metabolism of the osseous fluid compartment is mediated by calcitropic hormones [107]. Endocrine factors are known to contribute to ameloblast function [108], osteolysis [75], and bone fluid metabolism [37, 66, 107], but there is no evidence for hormonal control of fluid perfusion through teeth.

Incorporation of $\mathrm{F}^{-}$into $\mathrm{HA}$ is a substitution for $\mathrm{OH}^{-}$ [109••]. HA is a sparingly soluble material with the chemical formula $\mathrm{Ca}_{10}\left(\mathrm{PO}_{4}\right) 6(\mathrm{OH})^{2}$, but spaces in the crystal matrix render it susceptible to acidic attack. The relatively rigid crystal structure is bound together with electrostatic forces that increase exponentially as the distance between positive and negative ions decreases (Coulomb's law). Since $\mathrm{F}^{-}$is smaller and more electronegative than $\mathrm{OH}^{-}$, substituting $\mathrm{F}^{-}$for $\mathrm{OH}^{-}$ results in tighter packing of the ions into an apatite crystal lattice. This configuration stabilizes the matrix by increasing the attraction forces between the cations and anion [109••]. Fluoride-rich apatite is deemed FA. FA is a tightly packed apatite crystal that is less susceptible to acidic attack, so it is a very important factor in prevention, pathogenesis, and treatment of dental demineralization [110-116].

The problem with optimal fluoridation of teeth and bones is the precise control of $\mathrm{F}^{-}$levels in saliva and ECF. If they are too low, inadequate FA is formed, but excessive $\mathrm{F}^{-}$levels, even if only transient, are toxic to mineralized tissue forming cells: osteoblasts (bone), ameloblasts (enamel), odontoblasts (dentin) [99, 106]. Optimal $\mathrm{F}^{-}$in the public water supply is more effective than oral administration for an optimal $\mathrm{F}^{-}$ effect in all age groups [89, 99, 100]. For young children still forming teeth, fluoridated tooth paste must be carefully administered to avoid fluorosis particularly if the water supply is also fluoridated [103-106]. Adolescents and adults achieve FA protection on the outer surface and within the enamel rods via cyclic remineralization of enamel. Since everyone is exposed to some degree of natural $\mathrm{F}^{-}$in the diet and water supply, it is hypothesized that FA formation via percolation is more common in the enamel sheath compared to the rod because of its naturally more porous mineral structure [93]. Optimal levels of $\mathrm{F}^{-}$in saliva increases demineralization resistance of the inter-rod substance by forming a gradient of FA that progressively decreases from the enamel surface. This is an important factor in caries pathogenesis (part II), but it is also a consideration in noncarious dental erosion (Fig. 2).

Hardening of dental enamel surfaces with variations of $\mathrm{F}^{-}$ treatment is effective for deceasing most forms of chemical and mechanical destruction of the dentition [24, 25, 27]. In addition, aminomethacrylate copolymer has the potential to enhance the anti-erosive effect of $\mathrm{F}^{-}$solutions [115]. Stannous chloride enhances the protective effect of $\mathrm{NaF}$. When dentin is exposed in cervical lesions, silver-diamminefloride (SDF) and potassium-iodide (KI) harden the exposed surface and have an antibacterial effect $[115,116]$.

Based on excellent caries control in dentistry, $\mathrm{F}^{-}$was evaluated for the treatment and prevention of OP [117-122]. Clinical trials of orally administered $\mathrm{F}^{-}$increased bone mineral density in the spine, but typical OP fractures were elevated because of the decreased mechanical strength of fluorotic bone $[117,118]$. It was hypothesized that oral administration of $\mathrm{F}^{-}$resulted in transient peaks that produced osseous fluorosis. Devices for slow release of $\mathrm{NaF}$ validated the efficacy and safety of $\mathrm{F}^{-}$treatment for OP when optimal levels were maintained [119]. Re-evaluation of the original negative data for $\mathrm{F}^{-}$treatment is indicated [120]. The previous conclusion that $\mathrm{F}^{-}$was not effective for treatment for OP $[117,118]$ was based on two experimental problems: (1) inconsistent definition for the level of osteopenia and (2) inadequate control of $\mathrm{F}^{-}$levels [119]. Subsequent studies that combined oral $\mathrm{NaF}$ and estrogen demonstrated that mineral density is more readily controlled than the incidence of vertebral fractures [121]. Fluoride at about $1 \mathrm{ppm}$ in the water supply has a protective effect against OP fractures, but the fracture rate increases at levels $>4$ ppm [122].

Overall, medicine experienced the same problems as dentistry in the use of $\mathrm{F}^{-}$to prevent and treat disease. It is very difficult to control spikes in the $\mathrm{F}^{-}$level from oral doses. Fluorotic bone formed under ideal conditions $\left(<1 \mathrm{ppm} \mathrm{F}^{-}\right)$is more resistant to bone resorption much like FA incorporation into enamel. However, even a slight increase or transient spikes in $\mathrm{F}^{-}$levels may result in enamel fluorosis and weak fluorotic bone $[117,118]$. Fluoride supplements mediate their actions through specific genetic signaling pathways, so a level 
that results in fluorotic enamel and bone in one individual may not in another [123]. All considered, the US Public Health Service decreased the recommended $\mathrm{F}^{-}$concentration in water to $0.7 \mathrm{mg} / \mathrm{L}$ (or $0.7 \mathrm{ppm}$ ) to balance the prevention of demineralization against the risk of dental fluorosis [99].

\section{Biomechanics}

Function, locomotion, and flexure of teeth and bones is thought to enhance fluid percolation through bones and teeth. However, exposure to repetitive mechanical loads results in accumulation of fatigue damage [76]. Mineral crystals have a limited capacity to maintain material integrity in a functional environment via fluid percolation, but the sensing mechanisms if any for mineral adaptation are unclear. Fluid percolates through enamel and optimizes physical properties by maintaining crystalline integrity of HA [124]. Formation of FA further stabilizes the mineral component and inhibits demineralization. However, the demineralization protection is probably a gradient favoring the enamel surface because formation of FA results in denser mineral that inhibits fluid flow. Dental loading induces a transient flux in the microporosity fluid which may produce mechanical signals at the dentinal interface (Fig. 2) [124]. The DEJ is a very sensitive area well known to restorative dentists because a patient must be well anesthetized to achieve pain-free operative dentistry when the DEJ is surgically penetrated. The physiologic biomechanics of enamel and DEJ function are difficult to study [125], but the mechanism can be indirectly evaluated following radiation therapy. Conventional wisdom (Frost) [16] holds that radiation-induced caries is due to decreased saliva production. However, a high level of therapeutic radiation directly damages enamel by decreasing its crystallinity and disrupting DEJ function. This compromise in normal enamel physiology contributes to radiation-induced caries [125].

\section{Pathologic Perspectives}

Mineralized tissues are affected by a broad array of biologic, chemical, and mechanical signals (Fig. 1) [33, 102]. It is clear that teeth can be severely damaged by noncarious demineralization, but most of the fundamental research on demineralization has focused on infectious caries [104, 126••, 127••]. Progress in understanding the pathophysiology of demineralization requires removing the variable of infection. However, caries must be integrated into the discussion because it is the most common clinical disorder. For example, acidic erosion of enamel (demineralization) is a complex process involving subsurface porosity (white spots) covered with a thin residual

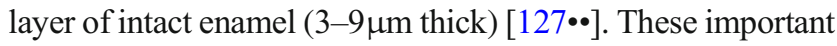
studies indicate that demineralization is not just a progressive surface erosion, but also involves remineralization of previously decalcified matrix much like initial enamel rod formation [38]. These data document how rapidly enamel can deteriorate when coated with plaque, but also show the potential for remineralization of residual matrix when a progressive lesion is arrested. The specific pathogenesis for dental caries is outside the scope of this report, but it will be discussed in detail in part II. However, a review of caries research is pivotal for defining the mechanism of demineralization, particularly via acidic erosion.

Loading is directly related to increased bone mass, enhanced repair of microdamage, and demineralization in a sterile environment (Fig. 1); however, inadequate loading (disuse atrophy) results in a loss of bone mass by osteoclastic resorption $[4,14,37,39]$. Since teeth do not have the turnover capability of osseous tissue [16, 17], they are susceptible to fatigue damage, i.e., cracks and fractures due to the mechanical loading of occlusion and parafunction. Flexural loading of teeth may create surface cracks that enhance demineralization particularly in stress risers at the base of cervical lesions (Fig. 2). Acidic demineralization is the mediator of mineralized tissue loss by either erosion or cell-mediated resorption [13, 16, 17, 24, 25]. Cellular (clastic) resorption within the oral cavity is rare, but it does occur with trauma-related cervical resorption near the gingival margin [112]. These often extensive lesions may be mistaken for root caries in a clinical or radiographic evaluation $[112,128]$. The etiology of cervical resorption is probably an immunologic response to injury [129] rather than erosion, abfraction, or caries $[35,36,104,127 \bullet \bullet]$. Teeth may appear discolored for many reasons including white spot formation, yellowing of enamel, root caries, cervical erosion, pulp necrosis, and/or the extensive secondary dentin formation with aging $[104,111,128,130]$.

A unique developmental process for enamel produces the most dense calcified tissue in the body: $\sim 96 \%$ inorganic material (HA) and $4 \%$ organic material and water by weight [55-58]. In comparison, osseous tissue with the greatest mineral density is a nonvital sequestrum [131] and the abnormal bone of osteogenesis imperfecta (OI), i.e., brittle bone disease [132]. Medication-related oral necrosis of the jaw (MRONJ) results in exposed oral bone sequestra [131]. Under the influence of resorption-suppressing medications, e.g., bisphosphonates and denosumab, large sections of oral bone may die and hypermineralize to form a sequestrum particularly in areas of osseous infection [128]. Subsequently, compromised mucosa covering the nonvital sequestrum atrophies because there is no vascular supply traversing the dead bone, thereby exposing an MRONJ lesion in the oral cavity. Accelerated mineral deposition to form enamel, bone sequestrum, and OI bone may involve substantial incorporation of trace elements ( $\mathrm{Sr}, \mathrm{Zn}$, and $\mathrm{Cu}$ ) which affects mechanical properties [133]. However, hypermineralized sequestra [131] and 
OI bone $[132,134]$ are still at least $50 \%$ mineralized collagen so they are not nearly as hard or resorption resistant as enamel. Indeed, enamel is a unique genetic tissue that has no peer among other mineralized tissues relative to density, strength, rigidity, and hardness [38, 55-58].

\section{Demineralization}

The term is defined as leaching of $\mathrm{Ca}^{++}$and $\mathrm{PO}_{4}{ }^{-3}$ ions from the investing or supporting matrix of a mineralized tissue. Plaque often collects near gingival margins, so the cervical region of a crown is threatened by acid related demineralization as well as noncarious ablation effects due to lateral or non-axial dental loading (Fig. 2). The rod sheath, or interrod substance that connects each rod to adjacent prisms, plays an important role in enamel formation, maintenance, and remineralization $[38,127 \bullet \bullet]$. The interprismatic substance also mineralizes, but not as densely as the adjacent enamel rods. Although an enamel surface appears to be a solid structure, there is microporosity particularly in the inter-rod substance which is susceptible to preferential FA remineralization and yellow staining [130].

All dental mineralized tissues exposed in the oral cavity are susceptible to demineralization. Loss of mass is due to attrition, abfraction, erosion, or abrasion and/or caries [22, $25,135,136]$. Under either sterile or septic conditions, the disease process involves both chemical and mechanical factors (Figs. 1 and 2). Bones respond to mechanical loading and metabolic factors in a sterile environment. Acidosis and/or inadequate loading contributes to osteopenia [137] particularly in estrogen-deficient females [138]. On the other hand, mechanical loading enhances osseous mass but it contributes to loss of dental mineralized tissue (Fig. 1) [16, $17,25,76,87,135]$. Among the mineralized tissues, enamel is most resistant to net deterioration reflecting an imbalance favoring demineralization over remineralization [33, $39,102]$. However, even enamel is susceptible to an interaction to an array of detrimental factors such as dietary acid, gastric reflux, mastication, parafunction, or bacterial infection $[33,39,101,104,135]$.

\section{Mechanical Lesions}

In contrast to bone surfaces controlled with cellular activity, attrition, abrasion, and abfraction affect the surfaces of teeth. Abrasion is tooth wear in a septic (oral) environment. Degeneration is a pathophysiologic feature that elicits varying signs and symptoms. Bone attrition in the knee is usually quite painful as evidenced by the clinical course for osteoarthritis (OI) [11]. On the other hand, dental attrition and TMJ degeneration may be debilitating, but the loss of mineralized tissue in the jaws rarely results in physical pain $[32,45]$. Parafunction (clenching and/or bruxism) is often a clinical feature of TMJ dysfunction. Physiologic stress, anxiety, and depression are common factors in the clinical course of temporomandibular disorder (TMD) [32, 45, 139]. Excessive functional activity may result in tired or sore facial muscles, but the marked facial pain attributed to TMD is usually myofascial in origin (muscle spasms) [139, 140]. Wear of enamel per se does not result in pain because it is a nonvital tissue; however, tooth fracture or erosion extending to the vital DEJ and dentin may elicit sensitivity and pain [67, 68, 141]. Severe dental wear and fractured teeth are more common with parafunction of neurologic origin particularly when medication is required [142, 143]. Thus, restoration of a worn or damaged dentition due to parafunction requires strong, wearresistant materials [78]. However, TMD management focuses on the etiology: stress, anxiety, and depression [32, 45, 139].

Mechanical wear of the dental mineralized tissues is deemed attrition or abrasion. Attrition refers to functional occlusal surfaces while abrasion is hard tissue loss on other oral surfaces (buccal or lingual). Enamel may be worn away by a gritty diet, functional occlusion, or parafunction [139-146]. On the other hand, cervical (class V) lesions are surface defects near the gingival margin. They are rarely in occlusal contact but may be sensitive lesions (Fig. 2). Cervical lesions are immediately coronal to the gingival margin and have a common prevalence of $85 \%$ with incidence of $18 \%$ [27]. They are classified according to etiology as erosion, abrasion, or abfraction [25-27]. An acidic diet particularly with low $\mathrm{pH}$ beverages like carbonated soda and wine demineralize enamel surfaces. Most foods including phytoliths (minute mineral particles) in plants are known to be abrasive. Superimposing mechanical factors such as toothbrush abrasion, coarse diet, and compressive flexure (abfraction) increases the prevalence of cervical lesions. The defects are usually on buccal surfaces of the dentition and are particularly common for teeth exposed to crown flexure due to heavy mastication or parafunction [25-27].

Mineral loss within enamel may be reversible, but surface attrition of teeth is a permanent loss of mineralized tissue [10, 85]. The wear of enamel is minimal with normal mastication, but bruxism and/or clenching are damaging long term [143-145]. Conventional wisdom (Frost) [16] holds that bruxism is a nocturnal habit, but that concept was not confirmed in a well-controlled sleep study [144]. Managing diurnal (daytime) parafunction requires a revision in clinical strategy [146]. Daytime clenching is also associated with clear aligner therapy [147].

Habitual, stress-related nocturnal clenching subjects the dental tissues to fatigue failure which may be manifest as split teeth, cusp fractures, and TMJ degeneration [32, 45, 148]. Bruxism results in excessive wear and it is particularly prevalent in stressed females [145]. Cracks in the outer enamel 
layer are common, but propagation is constrained by the radiating pattern of the rod structure $[149,150]$. With normal saliva output, cracks rarely become carious. However, crackrelated caries is common in patients with decreased salivary flow due to head and neck radiation [151], or methamphetamine abuse [152]. On the other hand, sustained loss of internal mineral from deep cervical lesions (Fig. 2) may result in tooth fracture, pulp inflammation, and devitalization, as well as periapical bone infection [27].

Treatment of dental attrition, abrasion, and TMJ degeneration is controversial. In the absence of profound structural damage, dental abrasion is relatively innocuous, and its management is often a patient-driven process based on selfperceived esthetics [153]. However, attrition (wear facets) and myofascial pain associated with TMD are typically managed with hard methyl methacrylate or soft ethylene-vinyl acetate orthotics. These are occlusal coverage devices commonly referred to in dentistry as "splints" but the preferred term in medicine is an orthotic (device to control movable parts). An occlusal coverage orthotic distributes the functional loads over the entire arch. The device physically protects teeth from bruxism, the most common form of dental attrition [154], but no effectiveness in managing mechanical overloads (abfraction) has been demonstrated. However, dental flexure can be controlled with a neurologic orthotic to control biting strength [59] as will be described below. Prevention and interceptive care to control the progression of cervical defects is preferred because restoration of the lesion(s) is challenging. Cervical defects affect most of the population say $60 \%$, but the prevalence can be as high as $85 \%$ over a lifetime. Teeth demonstrating mechanical lesions should be carefully monitored to confirm the lesions are not progressing prior to restorative procedures (Fig. 2) [155, 156].

\section{Erosion}

Erosion can potentiate the demineralization of mechanical lesions, so cervical defects are classified according to etiology [27]. Acidic foods and beverages may demineralize exposed enamel, cementum, and dentin (Fig. 2); remineralization can be accomplished with HA and $\mathrm{F}^{-}$gels [157]. The acidic foods commonly associated with erosion are citrus fruits, pickles, and vinegar [158]. They may be consumed directly or as ingredients in recipes. There is a preference for acidic beverages in the western diet because they are refreshing particularly after physical exertion and they "clear the palate" for better appreciation of food. Beverages with high acid content include carbonated soda, citrus-based drinks, and wine. Natural fruit tannins are prevalent in higher quality wine which may have a pH 3.5 or less. The European culture of wine and cheese consumed together is a wise social strategy. The cheese buffers the acidity of the wine, tends to adhere to enamel surfaces, and supplies both calcium and phosphate ions for remineralization.

Overall, the dental erosive potential of the diet depends on the frequency, acidic strength, and the buffering capacity of all foods or ingredients consumed during the same meal or snack. Gastric regurgitation when associated with the frequent purging or other eating disorders may result in severe erosion particularly along the palatal surfaces of the maxillary dentition. Monitoring and treating this disorder [159-161] requires the support of psychology services. Salivary proteins and particularly hemoglobin protect against dental erosion related to gastric esophageal reflux disease (GERD) [159]. Assessing GERD damage on a regular basis is good clinical practice. Bioluminescence is a novel method for assessing patterns of demineralization on tooth surfaces exposed to erosion [161]. Stannous ions $\left(\mathrm{Sn}^{++}\right)$in mouth wash at $200 \mathrm{ppm}$ or more help protect teeth from erosion [160].

\section{Combined Etiology}

Mechanical flexure producing surface tension or compression may produce surface micro-cracks in the cervical region that facilitate demineralization particularly in an acidic environment $[25,135,136]$. Lateral or non-axial loads on the crown of a tooth result in flexure in the cervical area near the CEJ and soft tissue margin. This is the critical section: plane of maximal flexure in a restrained body such as a tooth firmly anchored in bone. A stress riser on a tooth produced by lateral or nonaxial loads is an area where the stress is significantly greater than the surrounding region. The length of the crown relative to supporting bone usually indicates the stress riser is located on the buccal or lingual surface in the cervical area (Fig. 2). Demineralization in the cervical area is potentiated by exposure to dietary acidity. The combination of environmental acidity and moderate flexural loading produces cervical erosion that tends to be broad with relatively smooth surfaces [24, 135].

Abfraction in the cervical area of the crown occurs when occlusal forces elicit pronounced flexure in the buccal or lingual plane that is perpendicular to the long axis of the tooth (Fig. 2). From a mechanical perspective, this is the critical section (greatest cross-sectional stress) for a restrained body [162]. Mineralized tissue (enamel, dentin, cementum) at the location of the stress riser occlusal to the CEJ are exposed to compressive and tensile stresses which cause microfracture and sluffing of mineralized tissue particles. This mechanically induced demineralization process is enhanced by an acidic environment or toothbrush abrasion (Fig. 2). When abfraction is the predominate etiology, cervical ditching is $V$-shaped and progressive because the deepest part of the lesion continues to be the stress riser (Fig. 2). Cervical lesions are hygiene problems that may retain plaque, support caries, elicit a hypersensitivity reaction, and result in loss of pulp vitality $[27,163]$. 
It is unknown if orthodontics contributes to cervical lesions associated with abfraction and abrasion, but the potential is certainly a concern. There is some indirect evidence for craniofacial anomaly patients that tooth movement contributes to tooth sensitivity and cervical lesions in some patients [164]. It is unlikely the relatively low static force $(<3 N)$ for orthodontic tooth movement is a direct risk because functional occlusal loads are hundreds of times greater. However, moving teeth does create transient occlusal interferences that may result in damaging tooth flexure that contributes to cervical abfraction. This mechanism of dental flexure has been described for the initiation of root resorption in genetically predisposed patients [165]. In addition, fixed appliance patients may tend to brush in a horizontal plane that produces abrasion in the cervical region (Fig. 2). Furthermore, enamel surfaces are altered when fixed appliances or aligner attachments are removed [166, 167]. It is unknown if altered enamel surfaces are predisposed to abfraction, but roughened enamel surfaces may retain plaque and facilitate caries [88]. Careful study to determine the incidence and nature of cervical lesions in orthodontic patients is indicated.

Effective management for mechanical destruction of teeth requires a thorough diagnosis and comprehensive treatment plan. Nocturnal and/or diurnal parafunction may contribute to abfraction. This problem is best controlled with a neurologic orthotic, i.e., a Hawley bite plate that opens the posterior bite slightly. It should not be worn at mealtimes to avoid extruding molars. Night wear is prescribed for nocturnal parafunction [59]. Daytime wear other than mealtime is indicated for diurnal parafunction [146]. Slight opening of posterior occlusion inhibits the polysynaptic reflex [168]' thereby blocking the maximal contraction of mandibular elevator muscles. Suppressing nocturnal clenching and bruxism by inhibiting this reflex arc is effective for managing mechanical overload of the dentition manifest as TMD [169], and TMJ degeneration [32, 45]. Attrition, erosion, abrasion, abfraction are controlled by correcting the diet, use of occlusal orthotics, careful hygiene procedures, and avoiding heavy loading of the dentition [163, 168, 169].

\section{Noncarious Cervical Lesions}

A common clinical manifestation of cervical erosion, abrasion, and/or abfraction is deemed noncarious cervical lesions (NCCLs). These unique problems in dentistry are quite prevalent $(\sim 50 \%)$ overall, but they are most common in adults $(\geq 60 \%)$ [84-87]. NCCLs are manifest as a loss of mineralized tissue along the tooth surface near the gingival margin independent of caries (Fig. 2). The etiology is abrasion, erosion, and occlusal trauma (wear facets) [86]. The etiology is variable, but flexure of teeth due to mechanical loading is a common feature of the disease process. Non-axial (lateral) loads associated with habitual clenching (parafunction) produce a surface flexure in the cervical area that exceeds the known failure stresses for enamel [87]. The maximum depth of a NCCL is a stress riser when the tooth is flexed, so abfraction tends to form and deepen a $V$-shaped lesion (Fig. 2). The focus on treatment should be controlling the etiology (parafunction) rather than restoration of the NCCLs. As previously mentioned, a neurologic orthotic (Hawley biteplate with slight posterior open bite) is effective for controlling parafunction between meals [32, 45, 168, 169].

NCCLs are a perplexing problem because a cervical lesion extending into dentin may result in tooth sensitivity [164] and pain which is difficult to differentiate from root sensitivity in adults with soft tissue recession. Furthermore, the presence of plaque in a previous NCCL may facilitate caries that infects the pulp $[33,36]$. In addition, acidic lozenges, tablets, and mouth rinses may potentiate demineralization [170, 171]. Caries is a serious complication for previous NCCLs in cervical and root areas because the width of dentin is relatively thin near the cementoenamel junction (Fig. 2). An active lesion can rapidly invade the pulp, devitalize the tooth, and infect its supporting bone. Biofilm studies in bone suggest a virulence to destroy osteogenic cells and degrade osseous tissue that is independent of host immunity and osteoclastogenesis [172-175]. Thus, dental biofilm infections of periapical bone may be an increasingly serious problem.

\section{Conclusion}

Demineralization of hard tissue involves biomechanics, metabolism, immune signaling, diet, and unhealthy lifestyle. Detrimental habits, psychologic stress, and infection can also play a role. Inadequate osseous structure is defined as osteopenia, but if it is severe and/or symptomatic, the diagnosis is OP. The etiology is typically an excessive resorption due to biomechanics (disuse atrophy) and metabolism (negative calcium balance). In the absence of dental caries, loss of tooth structure is usually attrition, abrasion, erosion, and abfraction. To effectively manage dental demineralization, diet, hygiene, and stressful lifestyle must be controlled. If the differential diagnosis indicates that parafunction is a contributing factor, a neurologic orthotic may be indicated indefinitely. Incidence and prevalence of NCCLs is a particular concern for elective dental treatment such as orthodontics.

Funding Open Access funding enabled and organized by CAUL and its Member Institutions.

\section{Declarations}

Conflict of Interest W. Eugene Roberts and Paul Schneider. declare no conflict of interest. Jonathan Magnum reports a grant, personal fees as an 
employee, and owning shares of Incisive Technologies, and has a patent issued (WO2011/113107A1).

Human and Animal Rights and Informed Consent This article does not contain any studies with human or animal subjects performed by any of the authors.

Open Access This article is licensed under a Creative Commons Attribution 4.0 International License, which permits use, sharing, adaptation, distribution and reproduction in any medium or format, as long as you give appropriate credit to the original author(s) and the source, provide a link to the Creative Commons licence, and indicate if changes were made. The images or other third party material in this article are included in the article's Creative Commons licence, unless indicated otherwise in a credit line to the material. If material is not included in the article's Creative Commons licence and your intended use is not permitted by statutory regulation or exceeds the permitted use, you will need to obtain permission directly from the copyright holder. To view a copy of this licence, visit http://creativecommons.org/licenses/by/4.0/.

\section{References}

Papers of particular interest, published recently, have been highlighted as:

- Of importance

•- Of major importance

1 The Power of the Human Jaw in Scientific American 1911 Dec;105(23):493 https://doi.org/10.1038/scientificamerican 12021911-493.

2 Daegling DJ, Hylander WL. Experimental observation, theoretical models, and biomechanical inference in the study of mandibular form. Am J Phys Anthropol. 2000 Aug;112(4):541-51.

3 Dechow PC, Hylander WL. Elastic properties and masticatory bone stress in the macaque mandible. Am J Phys Anthropol. 2000 Aug;112(4):553-74.

4.• Huja SS, Fernandez SA, Hill KJ, Li Y. Remodeling dynamics in the alveolar process in skeletally mature dogs. Anat Rec A Discov Mol Cell Evol Biol. 2006 Dec;288(12):1243-9. Documents that the mandible is the bone exposed to the highest level of flexure and microdamage

5. Hahn FL, Reygadas F. Demineralization of hard tissues. Science. 1951 Nov 2;114(2966):462-3. https://doi.org/10.1126/science. 114.2966 .462

6. Dedic C, Hung TS, Shipley AM, Maeda A, Gardella T, Miller AL, Divieti Pajevic P, Kunkel JG, Rubinacci A. Calcium fluxes at the bone/plasma interface: acute effects of parathyroid hormone (PTH) and targeted deletion of PTH/PTH-related peptide (PTHrP) receptor in the osteocytes. Bone. 2018 Nov;116:135-43.

7. Kim H, Oh B, Park-Min KH. Regulation of osteoclast differentiation and activity by lipid metabolism. Cells. 2021 Jan 7;10(1):89.

8. Cao H, Yan Q, Wang D, Lai Y, Zhou B, Zhang Q, Jin W, Lin S, Lei Y, Ma L, Guo Y, Wang Y, Wang Y, Bai X, Liu C, Feng JQ, Wu C, Chen D, Cao X, Xiao G. Focal adhesion protein Kindlin-2 regulates bone homeostasis in mice. Bone Res. 2020 Jan 2;8(1):2.

9. Uda Y, Azab E, Sun N, Shi C, Pajevic PD. Osteocyte mechanobiology. Curr Osteoporos Rep. 2017 Aug;15(4):318-25.

10. Pini NI, Sundfeld-Neto D, Aguiar FH, Sundfeld RH, Martins LR, Lovadino JR, Lima DA. Enamel microabrasion: an overview of clinical and scientific considerations. World J Clin Cases. 2015;3(1):34-41.
11. Hernández-Molina G, Neogi T, Hunter DJ, Niu J, Guermazi A, Reichenbach S, Roemer FW, McLennan CE, Felson DT. The association of bone attrition with knee pain and other MRI features of osteoarthritis. Ann Rheum Dis. 2008 Jan;67(1):43-7.

12. Eick S. Biofilms. Monogr Oral Sci. 2021;29:1-11.

13. Siddiqui JA, Partridge NC. Physiological bone remodeling: systemic regulation and growth factor involvement. Physiology (Bethesda). 2016;31(3):233-45.

14. Roberts WE, Huja SS, Roberts JA. Bone modeling: biomechanics, molecular mechanisms and clinical perspectives. Sem Orthod. 2004;10(2):123-61.

15. Meema HE, Oreopoulos DG, Meema S. A roentgenologic study of cortical bone resorption in chronic renal failure. Radiology. 1978 Jan;126(1):67-74.

16. Roberts WE, Roberts JA, Epker BN, Burr DB, Hartsfield JK Jr. Remodeling of mineralized tissues, part I: the Frost legacy. Sem Orthod. 2006;12(4):216-23.

17. Roberts WE, Roberts JA, Epker BN, Burr DB, Hartsfield JK Jr. Remodeling of mineralized tissues, part II: control and pathophysiology. Sem Orthod. 2006;12(4):238-53.

18. Kumar R, Tiwari AK, Tripathi D, Shrivas NV, Nizam F. Canalicular fluid flow induced by loading waveforms: a comparative analysis. J Theor Biol. 2019 Jun 21;471:59-73.

19. Abou Neel EA, Aljabo A, Strange A, Ibrahim S, Coathup M, Young AM, Bozec L, Mudera V. Demineralizationremineralization dynamics in teeth and bone. Int $\mathrm{J}$ Nanomedicine. 2016 Sep 19;11:4743-63.

20. Wright NC, Looker AC, Saag KG, Curtis JR, Delzell ES, Randall $\mathrm{S}$, Dawson-Hughes B. The recent prevalence of osteoporosis and low bone mass in the United States based on bone mineral density at the femoral neck or lumbar spine. J Bone Miner Res. 2014;29(11):2520-6.

21. Zamani M, Zamani V, Heidari B, Parsian H, Esmaeilnejad-Ganji SM. Prevalence of osteoporosis with the World Health Organization diagnostic criteria in the Eastern Mediterranean Region: a systematic review and meta-analysis. Arch Osteoporos. 2018;13:129.

22. Bahanan L, Singhal A, Zhao Y, Scott T, Kaye E. The association between food insecurity and dental caries among U.S. adults: Data from the National Health and Nutrition Examination survey. Community Dent Oral Epidemiol. 2021 Oct;49(5):464-470. https://doi.org/10.1111/cdoe.12622.

23. Listl S, Galloway J, Mossey PA, Marcenes W. (28 August 2015)Global economic impact of dental diseases. J Dent Res. 2016;94(10):1355-61.

24. Kassebaum NJ, Bernabé E, Dahiya M, Bhandari B, Murray CJ, Marcenes W. Global burden of untreated caries: a systematic review and metaregression. J Dent Res. 2015 May;94(5):650-8. https://doi.org/10.1177/0022034515573272. Epub 2015 Mar 4

25. Lussi A, Jaeggi T, Zero D. The role of diet in the aetiology of dental erosion. Caries Res. 2004;38(Suppl 1):34-44.

26. Richter S, Eliasson ST. Erosive and mechanical tooth wear in Viking age icelanders. Dent J (Basel). 2017 Aug 29;5(3):24.

27. Ceruti P, Menicucci G, Mariani GD, Pittoni D, Gassino G. Noncarious cervical lesions. A review. Minerva Stomatol. 2006 Jan-Feb;55(1-2):43-57.

28. Cui J, Liu H, Shao J, Xu DM, Wang Y, Fei Z, Wei J, Lu W, Wang CR, He R, Tan Y, Fan Y, Ning Y, Cassidy RM, Soares JC, Huang $\mathrm{X}$, Zhang XY. Prevalence, risk factors and clinical characteristics of osteoporosis in Chinese inpatients with schizophrenia. Schizophr Res. 2018 May;195:488-94.

29. Toward improving the oral health of Americans: an overview of oral health status, resources, and care delivery. Oral Health Coordinating Committee, Public Health Service. Public Health Rep. 1993;108(6):657-72. 
30. Dragomir-Daescu D, Rossman TL, Rezaei A, Carlson KD, Kallmes DF, Skinner JA, Khosla S, Amin S. Factors associated with proximal femur fracture determined in a large cadaveric cohort. Bone. 2018 Nov;116:196-202.

31. López-Frías FJ, Castellanos-Cosano L, Martín-González J, Llamas-Carreras JM, Segura-Egea JJ. Clinical measurement of tooth wear: tooth wear indices. J Clin Exp Dent. 2012;4(1):e4853.

32. Roberts WE, Stocum DL. Part II: Temporomandibular joint (TMJ)-regeneration, degeneration, and adaptation. Curr Osteoporos Rep. 2018 Aug;16(4):369-79. https://doi.org/10. 1007/s11914-018-0462-8.

33. Featherstone JD. The caries balance: contributing factors and early detection. J Calif Dent Assoc. 2003 Feb;31(2):129-33.

34. Mongeau SW. Dental readiness classifications and caries-risk assessment. Military Medicine. January 2008;173(suppl_1):42-7.

35. Diefenderfer KE, Stahl J. Caries remineralization therapy: implications for dental readiness. Military Medicine. January 2008;173(suppl_1):48-50.

36. Featherstone J. The continuum of dental caries - evidence for a dynamic disease process. J Dent Res. 2004;83:C39-42.

37. Roberts WE, Huja SS. Bone physiology, metabolism, and biomechanics in orthodontic practice. In: Graber LW, Vanarsdall RL, Vig KWL, Huang GJ, editors. Orthodontics: Current Principles and Techniques. 6th ed. Elsevier: St. Louis; 2017. p. 99-152.

38. Warshawsky H, Josephsen K, Thylstrup A, Fejerskov O. The development of enamel structure in rat incisors as compared to the teeth of monkey and man. Anat Rec. 1981 Aug;200(4):37199.

39. Roberts WE, Hartsfield JK Jr. Bone development and function: genetic and environmental mechanisms. Seminars in Orthodontics. 2004;10(2):100-22.

40. Depalle B, McGilvery CM, Nobakhti S, Aldegaither N, Shefelbine SJ, Porter AE. Osteopontin regulates type I collagen fibril formation in bone tissue. Acta Biomater. 2021 Jan 15;120: 194-202. https://doi.org/10.1016/j.actbio.2020.04.040.

41. Butler WT, Ritchie H. The nature and functional significance of dentin extracellular matrix proteins. Int J Dev Biol. 1995 Feb;39(1):169-79.

42. Holm NG. Glasses as sources of condensed phosphates on the early earth. Geochem Trans. 2014;15(8) Published 2014 Jun 6 https://doi.org/10.1186/1467-4866-15-8.

43. Dagdeviren D, Kalajzic Z, Adams DJ, Kalajzic I, Lurie A, Mednieks MI, Hand AR. Responses to spaceflight of mouse mandibular bone and teeth. Arch Oral Biol. 2018 Sep;93:163-76.

44. Bell CM, Soukup JW. Histologic, clinical, and radiologic findings of alveolar bone expansion and osteomyelitis of the jaws in cats. Vet Pathol. 2015 Sep;52(5):910-8.

45. Roberts WE, Goodacre CJ. The temporomandibular joint: a critical review of life-support functions, development, articular surfaces, biomechanics and degeneration. Journal of Prosthodontics. 2020;29:772-9.

46. Stocum DL, Roberts WE. Part I: development and physiology of the temporomandibular joint. Curr Osteoporos Rep. 2018 Aug;16(4):360-8.

47. Karimi A, Razaghi R, Biglari H, Rahmati SM, Sandbothe A, Hasani M. Finite element modeling of the periodontal ligament under a realistic kinetic loading of the jaw system. Saudi Dent J. 2020 Nov;32(7):349-56.

48. Yang L, Kang M, He R, Meng B, Pal A, Chen L, Jheon AH, Ho SP. Microanatomical changes and biomolecular expression at the PDL-entheses during experimental tooth movement. J Periodontal Res. 2019 Jun;54(3):251-8.

49. Cooper PR, Takahashi Y, Graham LW, Simon S, Imazato S, Smith AJ. Inflammation-regeneration interplay in the dentinepulp complex. J Dent. 2010 Sep;38(9):687-97.
50. Smith AJ, Cassidy N, Perry H, Bègue-Kirn C, Ruch JV, Lesot H. Reactionary dentinogenesis. Int J Dev Biol. 2007;51:173-6.

51. Iglesias-Linares A, Morford LA, Hartsfield J Jr. Bone density and dental external apical root resorption. Curr Osteoporos Rep. 2016 Dec;14(6):292-309.

52. Ramanathan C, Hofman Z. Root resorption in relation to orthodontic tooth movement. Acta Medica (Hradec Kralove). 2006;49(2):91-5.

53. Whittington J, Schoen E, Labounty LL, Hamdy R, Ramsey MW, Stone ME, Sands WA, Haff GG, Stone MH. Bone mineral density and content of collegiate throwers: influence of maximum strength. J Sports Med Phys Fitness. 2009 Dec;49(4):464-73.

54. Siminoski K, Lee KC, Abish S, et al. The development of bone mineral lateralization in the arms. Osteoporos Int: a Journal Established as Result of Cooperation Between the European Foundation for Osteoporosis and the National Osteoporosis Foundation of the USA. 2013 Mar;24(3):999-1006.

55. Margolis HC, Beniash E, Fowler CE. Role of macromolecular assembly of enamel matrix proteins in enamel formation. J Dent Res. 2006 Sep;85(9):775-93. https://doi.org/10.1177/ 154405910608500902.

56. Lacruz RS, Habelitz S, Wright JT, Paine ML. Dental enamel formation and implications for oral health and disease. Physiol Rev. 2017;97(3):939-93. https://doi.org/10.1152/physrev.00030.2016.

57. Habelitz S, Bai Y. Mechanisms of enamel mineralization guided by amelogenin nanoribbons. J Dent Res. 2021 May;19: 220345211012925-1443. https://doi.org/10.1177/ 00220345211012925. Epub ahead of print.

58. Bai Y, Yu Z, Ackerman L, Zhang Y, Bonde J, Li W, Cheng Y, Habelitz S. Protein nanoribbons template enamel mineralization. Proc Natl Acad Sci U S A. 2020 Aug 11;117(32):19201-8.

59. Smith CE, Hu Y, Hu JC, Simmer JP. Ultrastructure of early amelogenesis in wild-type, Amelx(-/-), and Enam(-/-) mice: enamel ribbon initiation on dentin mineral and ribbon orientation by ameloblasts. Mol Genet Genomic Med. 2016;4:662-83. https://doi.org/10.1002/mgg3.253.

60. Schneider PM, Silva M. Endemic molar incisor hypomineralization: a pandemic problem that requires monitoring by the entire health care community. Curr Osteoporos Rep. 2018 Jun;16(3):283-8.

61. Lee JJ, Morris D, Constantino PJ, Lucas PW, Smith TM, Lawn BR. Properties of tooth enamel in great apes. Acta Biomater. 2010 Dec;6(12):4560-5.

62. Goodacre CJ, Roberts WE, Goldstein G, Wiens JP. Does the stomatognathic system adapt to changes in occlusion? Best evidence consensus statement. J Prosthodont. 2021;30:5-11.

63. Bartlett JD, Skobe Z, Nanci A, Smith CE. Matrix metalloproteinase 20 promotes a smooth enamel surface, a strong dentinoenamel junction, and a decussating enamel rod pattern. Eur J Oral Sci. 2011 Dec;119(Suppl 1):199-205.

64. Mizumachi H, Yoshida S, Tomokiyo A, Hasegawa D, Hamano S, Yuda A, Sugii H, Serita S, Mitarai H, Koori K, Wada N, Maeda H. Calcium-sensing receptor-ERK signaling promotes odontoblastic differentiation of human dental pulp cells. Bone. 2017 Aug;101: 191-201.

65. Yang S, Choi H, Kim TH, Jeong JK, Liu Y, Harada H, Cho ES. Cell dynamics in Hertwig's epithelial root sheath are regulated by $\beta$-catenin activity during tooth root development. J Cell Physiol. 2020 Dec 30;236:5387-98. https://doi.org/10.1002/jcp.30243. Epub ahead of print.

66. Roberts WE. Bone physiology, metabolism and biomechanics in orthodontic practice. In: Graber LW, Vanarsdall Jr RL, KWL V, editors. Orthodontics: Current Principles and Techniques, Chapter 10. 5th ed. St. Louis: Elsevier Mosby; 2012. p. 287-343.

67. Andreasen JO, Ahrensburg SS, Tsilingaridis G. Root fractures: the influence of type of healing and location of fracture on tooth 
survival rates - an analysis of 492 cases. Dent Traumatol. 2012 Oct:28(5):404-9.

68. Jin H, Thomas HF, Chen J. Wound healing and revascularization: a histologic observation of experimental tooth root fracture. Oral Surg Oral Med Oral Pathol Oral Radiol Endod. 1996 Jan;81(1): 26-30.

69. Idelevich A, Baron R. Brain to bone: what is the contribution of the brain to skeletal homeostasis? Bone. 2018;115:31-42.

70. Streicher C, Heyny A, Andrukhova O, Haigl B, Slavic S, Schüler C, Kollmann K, Kantner I, Sexl V, Kleiter M, Hofbauer LC, Kostenuik PJ, Erben RG. Estrogen regulates bone turnover by targeting RANKL expression in bone lining cells. Sci Rep. 2017;7(1):6460.

71. Almeida M, Laurent MR, Dubois V, Claessens F, O'Brien CA, Bouillon R, Vanderschueren D, Manolagas SC. Estrogens and androgens in skeletal physiology and pathophysiology. Physiol Rev. 2017;97(1):135-87.

72. Huja SS, Beck FM, Thurman DT. Indentation properties of young and old osteons. Calcif Tissue Int. 2006 Jun;78(6):392-7.

73. Fleet JC. The role of vitamin D in the endocrinology controlling calcium homeostasis. Mol Cell Endocrinol. 2017 Sep 15;453:36-45.

74. Talmage RV, Mobley HT. The concentration of free calcium in plasma is set by the extracellular action of noncollagenous proteins and hydroxyapatite. Gen Comp Endocrinol. 2009 Jul;162(3): 245-50.

75. Tsourdi E, Jähn K, Rauner M, Busse B, Bonewald LF. Physiological and pathological osteocytic osteolysis. $J$ Musculoskelet Neuronal Interact. 2018;18(3):292-303.

76. Burr DB. Stress concentrations and bone microdamage: John Currey's contributions to understanding the initiation and arrest of cracks in bone. Bone. 2019 Oct;127:517-25.

77. Hill Gallant KM, Spiegel DM. Calcium balance in chronic kidney disease. Curr Osteoporos Rep. 2017 Jun;15(3):214-21.

78. Hammoudi W, Trulsson M, Svensson P, Smedberg JI. Long-term results of a randomized clinical trial of 2 types of ceramic crowns in participants with extensive tooth wear. J Prosthet Dent. 2020 Dec 7:S0022-3913(20)30651-X; https://doi.org/10.1016/j. prosdent.2020.08.041. Epub ahead of print

79. Lee K, Lee JY, Kim YH. Low grip strength and muscle mass increase the prevalence of osteopenia and osteoporosis in elderly women. Healthcare (Basel). 2021 Apr 16;9(4):476.

80. Cochrane NJ, Cai F, Huq NL, Burrow MF, Reynolds EC. New approaches to enhanced remineralization of tooth enamel. J Dent Res. 2010 Nov;89(11):1187-97.

81. Cochrane NJ. Prevention of decalcification in orthodontics. Master's Thesis in Orthodontics, University of Melbourne, Melbourne, Australia, 2013.

82. McKeever A. Management of white spot lesions. Master's Thesis in Orthodontics, University of Melbourne, Melbourne, Australia, 2017.

83. Senna P, Del Bel CA, Rösing C. Non-carious cervical lesions and occlusion: a systematic review of clinical studies. J Oral Rehabil. 2012 Jun;39(6):450-62.

84. Teixeira DNR, Thomas RZ, Soares PV, Cune MS, Gresnigt MMM, Slot DE. Prevalence of noncarious cervical lesions among adults: a systematic review. J Dent. 2020 Apr;95:103285. https:// doi.org/10.1016/j.jdent.2020.103285. Epub 2020 Jan 30

85. Xue J, Li W, Swain MV. In vitro demineralization of human enamel natural and abraded surfaces: a micromechanical and SEM investigation. J Dent. 2009 Apr;37(4):264-72.

86. Telles D, Pegoraro LF, Pereira JC. Incidence of noncarious cervical lesions and their relation to the presence of wear facets. J Esthet Restor Dent. 2006;18(4):178-83. discussion 184

87. Rees JS. The effect of variation in occlusal loading on the development of abfraction lesions: a finite element study. J Oral Rehabil. 2002 Feb;29(2):188-93.
88. Shellis RP. Formation of caries-like lesions in vitro on the root surfaces of human teeth in solutions simulating plaque fluid. Caries Res. 2010;44(4):380-9.

89. Hamba H, Nakamura K, Nikaido T, Tagami J, Muramatsu T. Remineralization of enamel subsurface lesions using toothpaste containing tricalcium phosphate and fluoride: an in vitro $\mu \mathrm{CT}$ analysis. BMC Oral Health. 2020 Oct 27;20(1):292.

90. Bronckers AL. Ion transport by ameloblasts during amelogenesis. J Dent Res. 2017 Mar;96(3):243-53.

91. Risnes $\mathrm{S}, \mathrm{Li} \mathrm{C}$. On the method of revealing enamel structure by acid etching. Aspects of optimization and interpretation. Microsc Res Tech. 2019 Oct;82(10):1668-80.

92. Souza Bomfim GH, Costiniti V, Li Y, Idaghdour Y, Lacruz RS. TRPM7 activation potentiates SOCE in enamel cells but requires ORAI. Cell Calcium. 2020 May;87:102187.

93. Orams HJ, Phakey PP, Rachinger WA, Zybert JJ. Ultrastructural changes in the translucent and dark zones of early enamel caries. J Oral Pathol. 1980 Jan;9(1):54-61.

94. Li Y, Liang C, Slemenda CW, Ji R, Sun S, Cao J, Emsley CL, Ma F, Wu Y, Ying P, Zhang Y, Gao S, Zhang W, Katz BP, Niu S, Cao $\mathrm{S}$, Johnston CC Jr. Effect of long-term exposure to fluoride in drinking water on risks of bone fractures. J Bone Miner Res. 2001 May;16(5):932-9.

95. SCHNEYER LH, PIGMAN W, HANAHAN L, GILMORE RW. Rate of flow of human parotid, sublingual, and submaxillary secretions during sleep. J Dent Res. 1956 Feb;35(1):109-14. https:// doi.org/10.1177/00220345560350010301.

96. Pedersen A, Sørensen CE, Proctor GB, Carpenter GH. Salivary functions in mastication, taste and textural perception, swallowing and initial digestion. Oral Dis. 2018 Nov;24(8):1399-416.

97. Valencia R, Espinosa R, Borovoy N, Pérez S, Ceja I, Saadia M. Deproteinization effectiveness on occlusal enamel surfaces and resultant acid etching patterns: an in vitro study. J Clin Pediatr Dent. 2018;42(6):434-41.

98. Steiger-Ronay V, Kuster IM, Wiedemeier DB, Attin T, Wegehaupt FJ. Erosive loss of tooth substance is dependent on enamel surface structure and presence of pellicle - an in vitro study. Arch Oral Biol. 2020 Apr;112:104686.

99. U.S. Department of Health and Human Services Federal Panel on Community Water Fluoridation. U.S. Public Health Service Recommendation for Fluoride Concentration in Drinking Water for the Prevention of Dental Caries. Public Health Rep. 2015;130(4):318-31.

100. Bruun C, Givskov H. Calcium fluoride formation in enamel from semi- or low-concentrated $\mathrm{F}$ agents in vitro. Caries Res. 1993;27(2):96-9.

101. Hicks J, Garcia-Godoy F, Flaitz C. Biological factors in dental caries: role of saliva and dental plaque in the dynamic process of demineralization and remineralization (part 1). J Clin Pediatr Dent. 2003 Fall;28(1):47-52.

102. Hicks J, Garcia-Godoy F, Flaitz C. Biological factors in dental caries enamel structure and the caries process in the dynamic process of demineralization and remineralization (part 2). J Clin Pediatr Dent. 2004 Winter;28(2):119-24. Erratum in: J Clin Pediatr Dent. 2004 Spring;38(3):214

103. Hicks J, Garcia-Godoy F, Flaitz C. Biological factors in dental caries: role of remineralization and fluoride in the dynamic process of demineralization and remineralization (part 3). J Clin Pediatr Dent. 2004 Spring;28(3):203-14.

104. Darling AI. The pathology and prevention of caries. British Dental Journal. 1959;107(10):287-302.

105. Hayes C, Douglass CW, Kim FM, Burgard SL, Couper D, National Osteosarcoma Etiology Group. A case-control study of topical and supplemental fluoride use and osteosarcoma risk. J Am Dent Assoc. 2021 Mar 18:S0002-8177(21)00043-X; https:// doi.org/10.1016/j.adaj.2021.01.010. Epub ahead of print 
106. Patil MM, Lakhkar BB, Patil SS. Curse of fluorosis. Indian J Pediatr. 2018 May;85(5):375-83.

107. Song L. Calcium and bone metabolism indices. Adv Clin Chem. 2017;82:1-46.

108. Jedeon K, Marciano C, Loiodice S, Boudalia S, Canivenc Lavier MC, Berdal A, Babajko S. Enamel hypomineralization due to endocrine disruptors. Connect Tissue Res. 2014 Aug;55(Suppl 1):43-7.

109.• Simmer JP, Hardy NC, Chinoy AF, Bartlett JD, Hu JC. How fluoride protects dental enamel from demineralization. J Int Soc Prev Community Dent. 2020 Apr 2;10(2):134-41. Explains the physical role of fluoride in conferring demineralization resistance

110. Nyvad B, Machiulskiene V, Baelum V. Reliability of a new caries diagnostic system differentiating between active and inactive caries lesions. Caries Res. 1999 Jul-Aug;33(4):252-60.

111. Gomez J. Detection and diagnosis of the early caries lesion. BMC Oral Health. 2015;15(Suppl 1):S3. https://doi.org/10.1186/14726831-15-S1-S3.

112. Gomez J, Tellez M, Pretty IA, Ellwood RP, Ismail AI. Noncavitated carious lesions detection methods: a systematic review. Community Dent Oral Epidemiol. 2013 Feb;41(1):54-66.

113. Bhandari R, Thakur S, Singhal P, Chauhan D, Jayam C, Jain T. In vivo comparative evaluation of esthetics after microabrasion and microabrasion followed by casein phosphopeptideamorphous calcium fluoride phosphate on molar incisor hypomineralization-affected incisors. Contemp Clin Dent. 2019;10(1):9-15.

114. Khoroushi M, Kachuie M. Prevention and treatment of white spot lesions in orthodontic patients. Contemp Clin Dent. 2017 JanMar;8(1):11-9.

115. Augusto MG, da Silva LFO, Scaramucci T, Aoki IV, Torres CRG, Borges AB. Protective effect of anti-erosive solutions enhanced by an aminomethacrylate copolymer. J Dent. 2020 Nov 26;105: 103540

116. Contreras V, Toro MJ, Elías-Boneta AR, Encarnación-Burgos A. Effectiveness of silver diamine fluoride in caries prevention and arrest: a systematic literature review. Gen Dent. 2017 MayJun;65(3):22-9.

117. Riggs BL, Hodgson SF, O'Fallon WM, Chao EY, Wahner HW, Muhs JM, Cedel SL, Melton LJ 3rd. Effect of fluoride treatment on the fracture rate in postmenopausal women with osteoporosis. N Engl J Med. 1990 Mar 22;322(12):802-9.

118. Reeve J, Davies UM, Hesp R, McNally E, Katz D. Treatment of osteoporosis with human parathyroid peptide and observations on effect of sodium fluoride [published correction appears in BMJ 1990 Sep 8;301(6750):477]. BMJ. 1990;301(6747):314-8.

119. Pak CY, Adams-Huet B, Sakhaee K, Bell NH, Licata A, Johnston C, Rubin B, Bonnick S, Piziak V, Graham H, Ballard J, Berger R, Fears W, Breslau N, Rubin C. Comparison of nonrandomized trials with slow-release sodium fluoride with a randomized placebo-controlled trial in postmenopausal osteoporosis. J Bone Miner Res. 1996 Feb;11(2):160-8.

120. Kleerekoper M. The role of fluoride in the prevention of osteoporosis. Endocrinol Metab Clin North Am. 1998 Jun;27(2):441-52.

121. Gutteridge DH, Stewart GO, Prince RL, Price RI, Retallack RW, Dhaliwal SS, Stuckey BG, Drury P, Jones CE, Faulkner DL, Kent GN, Bhagat CI, Nicholson GC, Jamrozik K. A randomized trial of sodium fluoride $(60 \mathrm{mg})+/-$ estrogen in postmenopausal osteoporotic vertebral fractures: increased vertebral fractures and peripheral bone loss with sodium fluoride; concurrent estrogen prevents peripheral loss, but not vertebral fractures. Osteoporos Int. 2002;13(2):158-70.

122. Godebo TR, Jeuland M, Tekle-Haimanot R, Shankar A, Alemayehu B, Assefa G, Whitford G, Wolfe A. Bone quality in fluoride-exposed populations: a novel application of the ultrasonic method. Bone Rep. 2019 Dec 7;12:100235.

123. Everett ET. Fluoride's effects on the formation of teeth and bones, and the influence of genetics. J Dent Res. 2011 May;90(5):55260.

124. Shen L, Barbosa de Sousa F, Tay N, Lang TS, Kaixin VL, Han J, Kilpatrick-Liverman L, Wang W, Lavender S, Pilch S, Gan HY. Deformation behavior of normal human enamel: a study by nanoindentation. J Mech Behav Biomed Mater. 2020 Aug;108: 103799.

125. Palmier NR, Migliorati CA, Prado-Ribeiro AC, de Oliveira MCQ, Vechiato Filho AJ, de Goes MF, Brandão TB, Lopes MA, SantosSilva AR. Radiation-related caries: current diagnostic, prognostic, and management paradigms. Oral Surg Oral Med Oral Pathol Oral Radiol. 2020 Jul;130(1):52-62.

126.• Darling CL, Huynh GD, Fried D. Light scattering properties of natural and artificially demineralized dental enamel at $1310 \mathrm{~nm} . \mathrm{J}$ Biomed Opt. 2006 May-Jun;11(3):34023. Explains why subsurface enamel decalcifications are invisible until they are about $400 \mu \mathrm{m}$ deep

127.• Holmen L, Thylstrup A, Ogaard B, Kragh F. A polarized light microscopic study of progressive stages of enamel caries in vivo. Caries Res. 1985;19(4):348-54. This is the only well documented report on caries induction in humans

128. Fee PA, Macey R, Walsh T, Clarkson JE, Ricketts D. Tests to detect and inform the diagnosis of root caries. Cochrane Database Syst Rev. 2020 Dec 7;12:CD013806.

129. Kandalgaonkar SD, Gharat LA, Tupsakhare SD, Gabhane MH. Invasive cervical resorption: a review. J Int Oral Health. 2013 Dec;5(6):124-30.

130. Wakasa M, Nakanishi K, Manago K, Isobe T, Eshita Y, Okamoto $\mathrm{M}$, Isshiki T. Fine structure of tooth enamel in the yellowing human teeth: SEM and HRTEM studies. Microsc Res Tech. 2016 Jan;79(1):14-22.

131. Komiya R, Wada T, Tsushima F, Sakamoto K, Ikeda T, Yamaguchi A, Harada H, Uo M. Quantitation and distribution of metallic elements in sequestra of medication-related osteonecrosis of jaw (MRONJ) using inductively coupled plasma atomic emission spectroscopy and synchrotron radiation X-ray fluorescence analysis. J Bone Miner Metab. 2019 Jul;37(4): 676-84.

132. Pragnère $\mathrm{S}$, Auregan JC, Bosser $\mathrm{C}$, Linglart $\mathrm{A}$, Bensidhoum $\mathrm{M}$, Hoc T, Nouguier-Lehon C, Chaussain C. Human dentin characteristics of patients with osteogenesis imperfecta: insights into collagen-based biomaterials. Acta Biomater. 2021 Jan 1;119: 259-67.

133. Dean MC, Spiers KM, Garrevoet J, Le Cabec A. Synchrotron Xray fluorescence mapping of $\mathrm{Ca}, \mathrm{Sr}$ and $\mathrm{Zn}$ at the neonatal line in human deciduous teeth reflects changing perinatal physiology. Arch Oral Biol. 2019 Aug;104:90-102.

134. Paterson CR, Burns J, McAllion SJ. Osteogenesis imperfecta: the distinction from child abuse and the recognition of a variant form. Am J Med Genet. 1993 Jan 15;45(2):187-92.

135. Chan AS, Tran TTK, Hsu YH, Liu SYS, Kroon J. A systematic review of dietary acids and habits on dental erosion in adolescents. Int J Paediatr Dent. 2020 Nov;30(6):713-33.

136. João-Souza SH, Bezerra SJC, de Freitas PM, de Lima NB, Aranha ACC, Hara AT, Scaramucci T. In situ evaluation of fluoride-, 
stannous- and polyphosphate-containing solutions against enamel erosion. J Dent. 2017 Aug;63:30-5.

137. Jehle S, Zanetti A, Muser J, Hulter HN, Krapf R. Partial neutralization of the acidogenic Western diet with potassium citrate increases bone mass in postmenopausal women with osteopenia. J Am Soc Nephrol. 2006 Nov;17(11):3213-22.

138. Olímpio RMC, Moretto FCF, De Sibio MT, de Oliveira M, Mathias LS, Gonçalves BM, Deprá IC, Tilli HP, Rodrigues BM, Saraiva PP, Maria DA, Nogueira CR. The importance of estrogen for bone protection in experimental hyperthyroidism in human osteoblasts. Life Sci. 2019 Aug 15;231:116556.

139. Yadav U, Ahmed J, Ongole R, Shenoy N, Sujir N, Natarajan S. Influence of psychosocial factors and parafunctional habits in temporomandibular disorders: a cross-sectional study. Perm J. 2020;24:19.144.

140. Atsü SS, Güner S, Palulu N, Bulut AC, Kürkçüoğlu I. Oral parafunctions, personality traits, anxiety and their association with signs and symptoms of temporomandibular disorders in the adolescents. Afr Health Sci. 2019 Mar;19(1):1801-10.

141. Hilton TJ, Funkhouser E, Ferracane JL, Gilbert GH, Gordan VV, Bennett S, Bone J, Richardson PA, Malmstrom H, National Dental PBRN Collaborative Group. Symptom changes and crack progression in untreated cracked teeth: one-year findings from the National Dental Practice-Based Research Network. J Dent. 2020 Feb;93:103269.

142. Kevilj R, Mehulic K, Dundjer A. Temporomandibular disorders and bruxism. Part I. Minerva Stomatol. 2007 Jul-Aug;56(7-8): 393-7.

143. Falisi G, Rastelli C, Panti F, Maglione H, Quezada Arcega R. Psychotropic drugs and bruxism. Expert Opin Drug Saf. 2014 Oct;13(10):1319-26.

144. Kapagiannidou D, Koutris M, Wetselaar P, Visscher CM, van der Zaag J, Lobbezoo F. Association between polysomnographic parameters of sleep bruxism and attrition-type tooth wear. J Oral Rehabil. 2021 Jan 21;48:687-91. https://doi.org/10.1111/joor. 13149. Epub ahead of print.

145. Carlsson GE, Egermark I, Magnusson T. Predictors of bruxism, other oral parafunctions, and tooth wear over a 20-year follow-up period. J Orofac Pain. 2003 Winter;17(1):50-7.

146. Goldstein RE, Auclair Clark W. The clinical management of awake bruxism. J Am Dent Assoc. 2017 Jun;148(6):387-91.

147. Lou T, Tran J, Castroflorio T, Tassi A, Cioffi I. Evaluation of masticatory muscle response to clear aligner therapy using ambulatory electromyographic recording. Am J Orthod Dentofacial Orthop. 2021 Jan;159(1):e25-33.

148. Mori H, Horiuchi S, Nishimura S, Nikawa H, Murayama T, Ueda K, Ogawa D, Kuroda S, Kawano F, Naito H, Tanaka M, Koolstra JH, Tanaka E. Three-dimensional finite element analysis of cartilaginous tissues in human temporomandibular joint during prolonged clenching. Arch Oral Biol. 2010 Nov;55(11):879-86.

149. Kim JH, Eo SH, Shrestha R, Ihm JJ, Seo DG. Association between longitudinal tooth fractures and visual detection methods in diagnosis. J Dent. 2020 Oct;101:103466.

150. Shi S, Li Y, Ngo-Dinh BN, Markmann J, Weissmüller J. Scaling behavior of stiffness and strength of hierarchical network nanomaterials. Science. 2021 Mar 5;371(6533):1026-33.

151. Palmier NR, Madrid CC, Paglioni MP, Rivera C, Martins BNFL, Araújo ALD, Salvajoli JV, de Goes MF, Lopes MA, Ribeiro ACP, Brandão TB, Santos-Silva AR. Cracked tooth syndrome in irradiated patients with head and neck cancer. Oral Surg Oral Med Oral Pathol Oral Radiol. 2018 Oct;126(4):335-341.e2.
152. Cossa F, Piastra A, Sarrion-Pérez MG, Bagán L. Oral manifestations in drug users: a review. J Clin Exp Dent. 2020 Feb 1;12(2): e193-200.

153. Bartlett D, O'Toole S. Tooth wear: best evidence consensus statement. J Prosthodont. 2020 Dec 17;30:20-5. https://doi.org/10. 1111/jopr.13312. Epub ahead of print.

154. Green JI. Prevention and management of tooth wear: the role of dental technology. Prim Dent J. 2016 Aug 1;5(3):30-3.

155. Peumans M, Politano G, Van Meerbeek B. Treatment of noncarious cervical lesions: when, why, and how. Int J Esthet Dent. 2020;15(1):16-42.

156. Nguyen C, Ranjitkar S, Kaidonis JA, Townsend GC. A qualitative assessment of non-carious cervical lesions in extracted human teeth. Aust Dent J. 2008 Mar;53(1):46-51.

157. Amaechi BT, AbdulAzees PA, Okoye LO, Meyer F, Enax J. Comparison of hydroxyapatite and fluoride oral care gels for remineralization of initial caries: a pH-cycling study. BDJ Open. $2020 \mathrm{Jul} 22 ; 6(1): 9$.

158. Hartz JJ, Procopio A, Attin T, Wegehaupt FJ. Erosive Potential of bottled salad dressings. Oral Health Prev Dent. 2021;19(1):51-7.

159. Martini T, Rios D, Dionizio A, Cassiano LPS, Taioqui Pelá V, E Silva CMS, Taira EA, Ventura TM, Magalhães AC, Carvalho TS, Baumann T, Lussi A, de Oliveira RB, Palma-Dibb RG, Buzalaf MAR. Salivary hemoglobin protects against erosive tooth wear in gastric reflux patients. Caries Res. 2020;54(5-6):466-74.

160. Moser C, Baumann T, Lussi A, Carvalho TS. Is the erosionprotective effect still maintained when tin concentrations are reduced in mouth rinse solutions? Caries Res. 2021 Feb 8:1-6.

161. Longbottom C, Vernon B, Perfect E, Haughey AM, Christie A, Pitts N. Initial investigations of a novel bioluminescence method for imaging dental demineralization. Clin Exp Dent Res. 2021 Jan 28;7:786-94. https://doi.org/10.1002/cre2.402. Epub ahead of print.

162. Litonjua LA, Andreana S, Bush PJ, Tobias TS, Cohen RE. Noncarious cervical lesions and abfractions: a re-evaluation. J Am Dent Assoc. 2003 Jul;134(7):845-50.

163. Rusu Olaru A, Popescu MR, Dragomir LP, Rauten AM. Clinical study on abfraction lesions in occlusal dysfunction. Curr Health Sci J. 2019 Oct-Dec;45(4):390-7.

164. Siqueira VDS, Castillo AES, Mateo-Castillo JF, Pinto LC, Garib D, Pinheiro CR. Dental hypersensitivity in individuals with cleft lip and palate: origin and therapies. J Dent Res Dent Clin Dent Prospects. 2021 Winter;15(1):42-6.

165. Al-Qawasmi RA, Hartsfield JK Jr, Everett ET, Flury L, Liu L, Foroud TM, Macri JV, Roberts WE. Genetic predisposition to external apical root resorption. Am J Orthod Dentofacial Orthop. 2003 Mar;123(3):242-52.

166. Sifakakis I, Zinelis S, Eliades G, Koletsi D, Eliades T. Enamel gloss changes induced by orthodontic bonding. J Orthod. 2018 Dec;45(4):269-74.

167. Eliades T, Papageorgiou SN, Ireland AJ. The use of attachments in aligner treatment: Analyzing the "innovation" of expanding the use of acid etching-mediated bonding of composites to enamel and its consequences. Am J Orthod Dentofacial Orthop. 2020 Aug;158(2): 166-74.

168. Hofstoetter US, Danner SM, Freundl B, Binder H, Lackner P, Minassian K. Ipsi- and contralateral oligo- and polysynaptic reflexes in humans revealed by low-frequency epidural electrical stimulation of the lumbar spinal cord. Brain Sci. 2021 Jan 16;11(1):112.

169. Lukic N, Saxer T, Hou MY, Zumbrunn Wojczyńska A, Gallo LM, Colombo V. Short-term effects of NTI-tss and Michigan splint on 
nocturnal jaw muscle activity: a pilot study. Clin Exp Dent Res. 2020 Dec 25;7:323-30. https://doi.org/10.1002/cre2.371. Epub ahead of print.

170. Delgado A, Dias Ribeiro AP, Aslam M, Olafsson VG, Pereira PN. Erosive assessment of dry mouth lozenges and tablets on enamel and dentin. J Dent. 2020 Dec 10;105:103496.

171. Delgado AJ, Dias Ribeiro AP, Quesada A, Rodríguez LE, Hernández R, Wynkoop B, Dilbone DA. Potential erosive effect of mouth rinses on enamel and dentin. Gen Dent. 2018 MayJun;66(3):75-9.

172. Kapellas K, Roberts-Thomson KF. National Study of Adult Oral Health 2017-18: root caries. Aust Dent J. 2020 Jun;65(Suppl 1): S40-6. https://doi.org/10.1111/adj.12763.

173. Junka A, Szymczyk P, Ziółkowski G, Karuga-Kuzniewska E, Smutnicka D, Bil-Lula I, Bartoszewicz M, Mahabady S,
Sedghizadeh PP. Bad to the bone: on in vitro and ex vivo microbial biofilm ability to directly destroy colonized bone surfaces without participation of host immunity or osteoclastogenesis. PLoS One. 2017 Jan 11;12(1):e0169565.

174. Kumar PS. From focal sepsis to periodontal medicine: a century of exploring the role of the oral microbiome in systemic disease. $\mathrm{J}$ Physiol. 2017 Jan 15;595(2):465-76.

175. Bagan L, Jiménez Y, Leopoldo M, Murillo-Cortes J, Bagan J. Exposed necrotic bone in 183 patients with bisphosphonaterelated osteonecrosis of the jaw: associated clinical characteristics. Med Oral Patol Oral Cir Bucal. 2017 Sep 1;22(5):e582-5.

Publisher's Note Springer Nature remains neutral with regard to jurisdictional claims in published maps and institutional affiliations. 